\title{
Sulfatase-Modifying Factor 1
}

National Cancer Institute

\section{Source}

National Cancer Institute. Sulfatase-Modifying Factor 1. NCI Thesaurus. Code C127893.

Sulfatase-modifying factor 1 ( $374 \mathrm{aa}, \sim 41 \mathrm{kDa}$ ) is encoded by the human SUMF1 gene.

This protein is involved in sulfatase oxidation. 